\title{
SELECTED DETERMINANTS OF EATING BEHAVIOURS AMONG PRESCHOOL CHILDREN FROM THE KRAKÓW ENVIRONMENT
}

\author{
Maria Gacek \\ ${ }^{1}$ Department of Sports Medicine and Human Nutrition, University School of Physical Education \\ in Kraków, Poland
}

\begin{abstract}
Background. One of the factors determining the nutritional behaviour of children and adolescents is family socio-economic status.

Objective. The aim of the study was to assess the nutritional behaviour of preschool children from the Kraków environment depending on the sex of the child and the mother's level of education.

Material and methods. The study was carried out among a group of mothers of 480 (240 girls and 240 boys) 4-6-yearolds, using the author's questionnaire on dietary behaviours. Children of mothers with higher education accounted for $63.5 \%$, and those with primary, vocational and secondary education constituted $36.5 \%$ of the group. Statistical analysis was carried out using the PQStat package 1.6.6.246 version, applying Pearson's Chi-squared test $(p<0.05)$.

Results. The girls consumed a significantly greater amount of: vegetables $(p<0.01)$, fruit $(p<0.05)$, wholemeal bread $(p<0.001)$ as well as milk and dairy products $(p<0.001)$, and boys: meat and cold-cuts from poultry $(p<0.001)$ and sweets $(p<0.05)$. Children of mothers with higher education more frequently consumed: vegetables $(p<0.001)$, fruit $(p<0.001)$, wholemeal bread $(p<0.001)$, fish $(p<0.01)$ and eggs $(p=0.01)$, and children of mothers with secondary and vocational education: milk and dairy products $(\mathrm{p}<0.05)$, meat and cold-cuts from poultry $(p<0.001)$ and sweets $(p=0.001)$, salted snacks $(p<0.001)$ and sweetened fizzy beverages $(p<0.05)$.

Conclusions. Diversity in some dietary choices of preschool children from the Kraków environment has been demonstrated, depending on the sex of children and the mother's level of education. Furthermore, it is indicated that girls and the children of mother's with higher education are characterised by a more favourable diet.
\end{abstract}

Key words: preschool children, nutritional behaviour, mother's level of education, Poland

\section{STRESZCZENIE}

Wprowadzenie: Jednym z czynników warunkujących zachowania żywieniowe dzieci i młodzieży jest status społeczno-ekonomiczny rodziny.

Cel. Celem badań była ocena zachowań żywieniowych dzieci przedszkolnych ze środowiska krakowskiego w zależności od płci dziecka oraz poziomu wykształcenia matki.

Materiał i metody. Badania przeprowadzono w grupie matek 480 dzieci (240 dziewcząt i 240 chłopców) w wieku 4-6 lat z zastosowaniem autorskiego kwestionariusza zachowań żywieniowych. Dzieci matek z wykształceniem wyższym stanowiły $63.5 \%$, a z zasadniczym zawodowym i średnim 36.5\% grupy. Analizę statystyczną przeprowadzono w pakiecie PQStat wersja 1.6.6.246. z zastosowaniem testu Chi-kwadrat $(p<0,05)$.

Wyniki. Dziewczęta istotnie częściej spożywały: warzywa $(p<0.01)$, owoce $(p<0.05)$, pieczywo razowe $(p<0.001)$ oraz mleko i jego przetwory $(p<0.001)$, a chłopcy: mięso i wędliny drobiowe $(p<0.001)$ oraz słodycze $(p<0.05)$. Dzieci matek z wykształceniem wyższym z większą częstością spożywały: warzywa $(p<0.001)$, owoce $(p<0.001)$, pieczywo razowe $(p<0.001)$, ryby $(p<0.01)$ i jaja $(p=0.01)$, a dzieci matek z wykształceniem nie-wyższym (średnim i zawodowym): mleko i jego przetwory $(p<0.05)$, mięso i wędliny drobiowe $(p<0.001)$ oraz słodycze $(p=0.001)$, słone przekąski $(p<0.001)$ i słodkie napoje gazowane $(p<0.05)$.

Wnioski. Wykazano zróżnicowanie niektórych wyborów żywieniowych dzieci przedszkolnych ze środowiska krakowskiego w zależności od płci dzieci oraz poziomu wykształcenia ich matek, ze wskazaniem na korzystniejszy sposób żywienia dziewcząt niż chłopców oraz dzieci matek z wykształceniem wyższym niż średnim i zasadniczym zawodowym.

Słowa kluczowe: dzieci przedszkolne, zachowania żywieniowe, poziom wykształcenia matki

Corresponding author: Maria Gacek, Department of Sports Medicine and Human Nutrition, University School of Physical Education, Al. Jana Pawła II 78, 31-571 Kraków, Poland, phone: +48 12683 14 45, fax: +48 12683 12 23, e-mail: maria.gacek@awf.krakow.pl

(C) Copyright by the National Institute of Public Health - National Institute of Hygiene 


\section{INTRODUCTION}

A correct, balanced way of feeding children and adolescents promotes the optimisation of development processes and the prevention of diet-related diseases, including obesity and its complications at later stages of ontogenesis $[16,18]$. Improving the health potential of children and adolescents is favoured through a varied diet, rich in products with high nutritional density, including vegetables and fruit, whole-grain cereals, milk and dairy products, lean meat and fish as well as nuts, with limited consumption of low-density products, including sweets and confectionery products, sweetened fizzy beverages and fast food $[10,14]$. The new Polish proposal within this aspect is the Pyramid of Healthy Nutrition and Lifestyle for Children and Youth (age 4-18) of the Institute of Food and Nutrition, published in January 2019. The nutritional part of the pyramid, at the base, starts with vegetables and fruits, and at the top, the pyramid is closed by vegetable oils and nuts. The intermediate levels are successively: whole-grain cereal products, milk and dairy products and other protein products (legume seeds, white meat, fish, eggs). It is also recommended to drink water and other non-sugary drinks, to not eat sweets or consume sugary drinks, limiting salt to herbs and other spices. The element of health creation for children and adolescents is also daily physical activity for at least one hour, sleep hygiene and counteracting body height and mass [13].

The specific nutritional needs of preschool children include a balanced diet, covering energy needs, protein, vitamins (including D3) and minerals (including calcium and iron). The proper supply of proteins and B group vitamins affects the normal course of metabolic processes, the normative intake of vitamin D3 and calcium optimises the building of peak bone mass, and the correct intake of iron prevents anaemia, one of the most frequently occurring paediatric problems $[10,13,14]$.

Nutritional behaviours of children and adolescents are a derivative of the influence of family and preschool or the school environment, while the attitudes and nutritional habits shaped at this age influence eating habits in later life. Research has shown that the socioeconomic status of a family is a factor influencing the health behaviour of children and teenagers, apart from demographic and cultural conditions $[1,6,19]$.

The premise for undertaking research was assuming the importance of the family environment in shaping children's eating habits. The aim of the study was to assess the nutritional behaviours of preschool children from the Kraków environment depending on sex and the mother's level of education (higher education vs. non-higher: secondary and vocational).

\section{MATERIAL AND METHODS}

The study was conducted using the auditorium questionnaire method among a randomly selected group of 480 parents of preschool age children in Kraków using the author's original validated questionnaire. The survey was prepared on the basis of current recommendations and subject-related literature $[10,13,14,42]$. The questionnaire addressed to mothers included metric questions concerning sociometric characteristics of the family (place of residence, age, education and occupational activity of parents, financial situation and family income, number of people in the household, number of children in the family) and concerning preschool children (age, gender, body mass and height). The main part of the questionnaire concerned the manner of feeding children (the number and regularity of eating meals, the frequency of consuming selected products, the number and type of preferred beverages). Statistical analysis was carried out using the PQStat, 1.6.6.246 version statistical package, applying Pearson's Chi-squared test, assuming test probability at the level of $p<0.05$.

The sociodemographic characteristics of the group show that the majority of subjects lived in the city (93.5\%), and a small percentage (6.5\%) lived in the outskirts. The mothers of the studied children were in majority, women between the age of 25 and $35(65.0 \%)$, those with higher education $(63.5 \%)$ and those professionally active (79.3\%). Almost half of the subjects $(44.0 \%)$ estimated their average, monthly family income to be above PLN 5,000, and a small percentage $(6.5 \%)$ stated the amount to be below PLN 1,500 . More than half of the subjects $(58.9 \%)$ assessed the family's financial situation as good, and a small percentage $(6.5 \%)$, as bad. The number of people in the household ranged from 2 to 7 individuals, 4-person families dominating $(53.8 \%)$. The number of children in families ranged from 1 to 3 , while families with 2 children dominated (53.8\%).

The studied group included 240 girls (50\%) and 240 boys $(50 \%)$ aged 4 to 6 years, the majority being 5 -yearolds $(63.5 \%)$. The children covered by the examination, in addition to home nutrition, also used mass nutrition at a preschool institution. The group was dominated by children remaining in preschool for 7-8 $\mathrm{h}(79.3 \%)$, less often, 9-11 h (20.7\%). Children of mothers with higher education accounted for $63.5 \%(\mathrm{~N}=308)$, and those with non-higher education (secondary and vocational) totalled $36.5 \%$ of the group $(\mathrm{N}=172)$. On the basis of the BMI index (with reference to Polish standards for children) [21], it was found that the majority of boys $(55.0 \%)$ and girls $(72.1 \%)$ were within the norm. At the same time, $17.9 \%$ of girls and $45.0 \%$ of boys were underweight. Overweightness and obesity occurred only in girls (respectively: $7.9 \%$ and $2.1 \%$ ). 


\section{RESULTS}

The preschool children in the study group were dominated by those who regularly consumed (93.5\%) 5 meals a day $(65.0 \%)$, eating meals together with their parents $(87.5 \%)$ and snacking between main meals $(86.4 \%)$ (Table 1). Analysis of the qualitative aspects of the discussed nutritional habits showed that the sex of children significantly differentiates the standard number of meals during the day and consumption of meals together with parents. In this regard, it was found that boys more often consumed at least 6 meals a day
$(12.1 \%$ vs $7.9 \%, p<0.05)$, and a greater percentage of girls e consumed meals together with their parents $(95.0 \%$ vs. $80.0 \%, p<0.001)$. It was also shown that the level of the mother's education significantly differentiates all of the discussed aspects. Children of mothers with higher education significantly more regularly $(p<0.001)$ consumed a larger number of meals during the day $(p<0.01)$, together with their parents $(\mathrm{p}=0.001)$, while a greater percentage of children of mothers with non-higher (secondary and vocational) education snacked between main meals more often $(p<0.001)$ (Table 1).

Table 1. Selected qualitative aspects of the diet of preschool children depending on sex and mother's level of education (percentage of subjects)

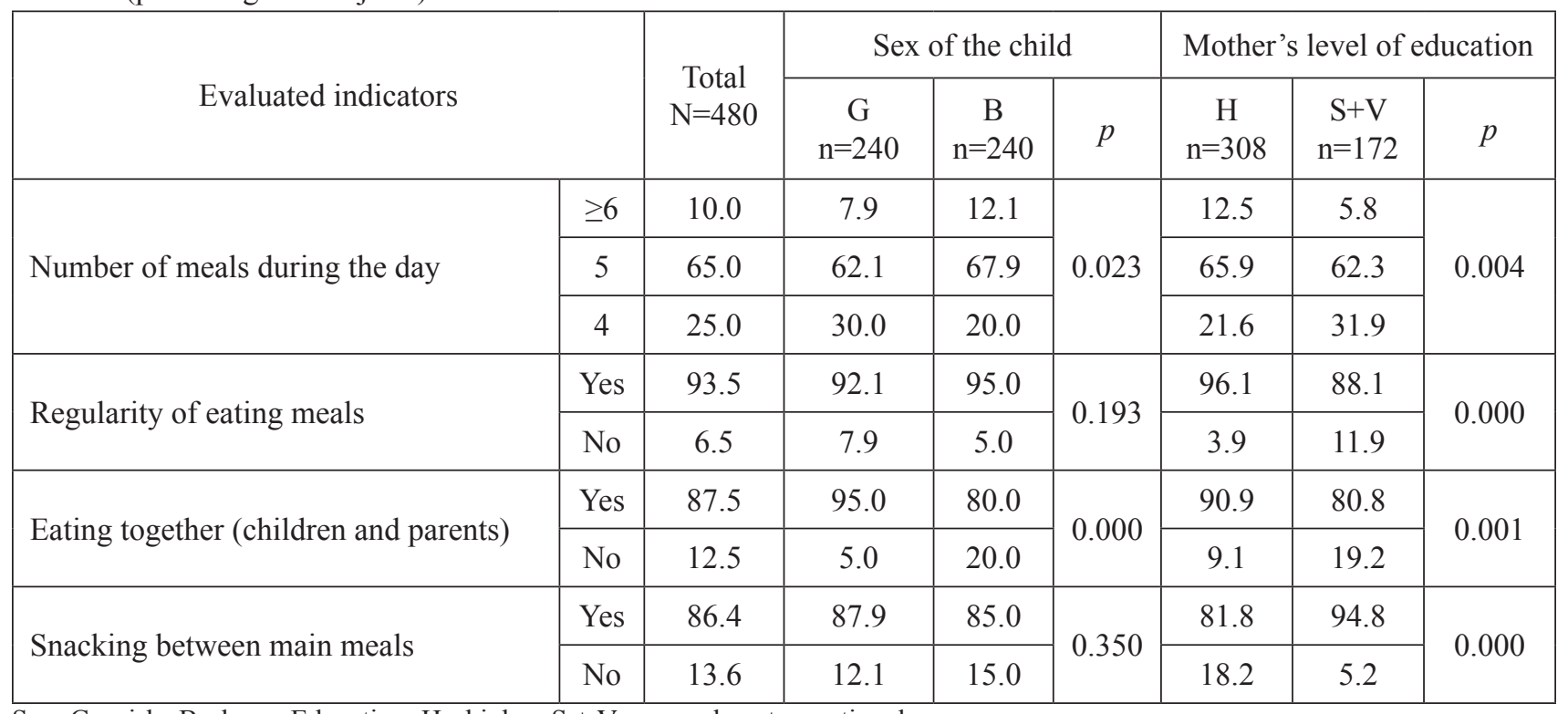

Sex: G - girls, B - boys; Education: H - higher, S + V - secondary + vocational

Assessment of the frequency of consuming selected groups of food products showed that preschool children, in their total daily diets, included the largest percentage of: fruit $(79.3 \%)$, milk and dairy products $(64.3 \%)$ and vegetables $(44.0 \%)$. They frequently consumed, several times a week: poultry meat and cold-cuts (93.5\%), eggs (88.1\%), fish (67.15), wholemeal bread $(58.9 \%)$, sweets/confectionery products $(56.8 \%)$ and vegetables $(50.9 \%)$. At the same time, less than once a month or never, they consumed: wholemeal bread $(25.5 \%)$ and fish $(12.1 \%)$, but also salted snacks/fast food (37.1\%) and sweets/ confectionery products $(21.9 \%)$. Statistical analysis confirmed variation in the frequency of consuming the majority of products included in relation to the sex of children and the level of education of their mothers. Girls consumed vegetables at a higher frequency $(p<0.01)$, fruit $(\mathrm{p}<0.05)$, wholemeal bread $(p<0.001)$ as well as milk and dairy products $(p<0.001)$, while boys consumed poultry meat and cold-cuts $(p<0.001)$ as well as sweets/confectionery products $(p<0.05)$. In turn, children of mothers with higher education consumed vegetables $(p<0.001)$, fruit $(p<0.001)$, wholemeal bread $(p<0.001)$, fish $(p<0.01)$ and eggs $(p=0.01)$ more frequently, and the children of mothers with non-higher education (secondary and vocational) consumed the following more often: milk and dairy products $(p<0.05)$, poultry meat and cold-cuts $(p<0.001)$, sweets/confectionery products $(p=0.001)$ and salted snacks/fast food $(p<0.001)$ (Table 2).

Assessment of the amount of consumed liquids and the type of preferred beverages showed that preschool children generally drank 1.0-1.5 and 0.5-1.0 litres of liquids a day, usually reaching for: mineral water $(33.5 \%)$ and tea $(20.4 \%)$. Statistical analysis confirmed diversity in the amount of beverages consumed depending on the sex of children and preferences depending on the mother's level of education. The boys consumed a greater volume of liquids than girls $(p<0.001)$, and the children of mothers with nonhigher (secondary and vocational) education preferred a higher percentage of consuming sweetened fizzy beverages $(p<0.05)$ (Table 3$)$. 
Table 2. Frequency of consuming selected product groups among preschool children depending on sex and the mother's level of education (percentage of subjects)

\begin{tabular}{|c|c|c|c|c|c|c|c|c|}
\hline \multirow[b]{2}{*}{ Food products } & \multirow{2}{*}{$\begin{array}{l}\text { Frequency of } \\
\text { consumption }\end{array}$} & \multirow{2}{*}{$\begin{array}{c}\text { Total } \\
\mathrm{N}=480\end{array}$} & \multicolumn{3}{|c|}{ Sex of the child } & \multicolumn{3}{|c|}{ Mother's level of education } \\
\hline & & & $\begin{array}{c}\mathrm{G} \\
\mathrm{n}=240\end{array}$ & $\begin{array}{c}B \\
n=240\end{array}$ & $p$ & $\begin{array}{c}\mathrm{H} \\
\mathrm{n}=308\end{array}$ & $\begin{array}{c}\mathrm{S}+\mathrm{V} \\
\mathrm{n}=172\end{array}$ & $p$ \\
\hline \multirow[t]{4}{*}{ Vegetables } & Every day & 44.0 & 48.0 & 40.0 & \multirow[t]{4}{*}{0.005} & 34.2 & 26.2 & \multirow[t]{4}{*}{0.000} \\
\hline & A few times a week & 50.9 & 48.2 & 53.7 & & 52.9 & 62.8 & \\
\hline & Once a month & 2.9 & 3.8 & 2.1 & & 12.9 & 6.9 & \\
\hline & Rarely / never & 2.2 & 0.0 & 4.2 & & 0.0 & 4.1 & \\
\hline \multirow[t]{4}{*}{ Fruit } & Every day & 79.3 & 80.8 & 77.9 & \multirow[t]{4}{*}{0.035} & 86.2 & 69.8 & \multirow[t]{4}{*}{0.000} \\
\hline & A few times a week & 19.6 & 17.1 & 22.1 & & 12.9 & 30.2 & \\
\hline & Once a month & 1.1 & 2.1 & 0.0 & & 0.9 & 0.0 & \\
\hline & Rarely / never & 0.0 & 0.0 & 0.0 & & 0.0 & 0.0 & \\
\hline \multirow[t]{4}{*}{ Wholemeal bread } & Every day & 8.5 & 12.1 & 5.0 & \multirow[t]{4}{*}{0.000} & 12.4 & 1.9 & \multirow[t]{4}{*}{0.000} \\
\hline & A few times a week & 58.9 & 62.9 & 55.0 & & 63.9 & 51.7 & \\
\hline & Once a month & 7.1 & 7.1 & 7.1 & & 4.9 & 8.7 & \\
\hline & Rarely / never & 25.5 & 17.9 & 32.9 & & 18.8 & 37.7 & \\
\hline \multirow{4}{*}{$\begin{array}{l}\text { Milk and dairy } \\
\text { products }\end{array}$} & Every day & 64.3 & 65.8 & 62.9 & \multirow[t]{4}{*}{0.000} & 62.9 & 69.8 & \multirow[t]{4}{*}{0.015} \\
\hline & A few times a week & 28.5 & 32.1 & 25.0 & & 27.9 & 27.9 & \\
\hline & Once a month & 4.7 & 2.1 & 7.1 & & 5.3 & 1.7 & \\
\hline & Rarely / never & 2.5 & 0.0 & 5.0 & & 3,9 & 0.6 & \\
\hline \multirow{4}{*}{$\begin{array}{l}\text { Poultry meat and } \\
\text { cold-cuts }\end{array}$} & Every day & 2.9 & 2.9 & 2.9 & \multirow[t]{4}{*}{0.000} & 0.9 & 6.9 & \multirow[t]{4}{*}{0.000} \\
\hline & A few times a week & 93.5 & 90.0 & 97.1 & & 92.9 & 93.1 & \\
\hline & Once a month & 2.5 & 5.0 & 0.0 & & 4.3 & 0.0 & \\
\hline & Rarely / never & 1.1 & 2.1 & 0.0 & & 1.9 & 0.0 & \\
\hline \multirow[t]{4}{*}{ Fish } & Every day & 0.0 & 0.0 & 0.0 & \multirow[t]{4}{*}{0.396} & 0.0 & 0.0 & \multirow[t]{4}{*}{0.002} \\
\hline & A few times a week & 67.1 & 70.0 & 64.2 & & 71.1 & 58.1 & \\
\hline & Once a month & 20.8 & 18.7 & 22.9 & & 21.8 & 22.7 & \\
\hline & Rarely / never & 12.1 & 11.3 & 12.9 & & 7.1 & 19.2 & \\
\hline \multirow[t]{4}{*}{ Eggs } & Every day & 1.5 & 0.5 & 2.1 & \multirow[t]{4}{*}{0.159} & 0.9 & 0.0 & \multirow[t]{4}{*}{0.010} \\
\hline & A few times a week & 88.1 & 88.7 & 87.9 & & 91.9 & 83.7 & \\
\hline & Once a month & 5.0 & 5.0 & 5.0 & & 3.9 & 8.8 & \\
\hline & Rarely / never & 5.4 & 5.8 & 5.0 & & 3.3 & 7.5 & \\
\hline Sweets & Every day & 1.3 & 0.5 & 2.1 & 0.011 & 0.9 & 0.0 & 0.001 \\
\hline & A few times a week & 56.8 & 62.9 & 50.8 & & 51.9 & 66.9 & \\
\hline & Once a month & 20.0 & 17.9 & 22.1 & & 25.0 & 12.2 & \\
\hline & Rarely / never & 21.9 & 18.7 & 25.0 & & 22.2 & 20.9 & \\
\hline Salted snacks / fast & Every day & 0.0 & 0.0 & 0.0 & 0.145 & 0.0 & 0.0 & 0.000 \\
\hline food & A few times a week & 34.4 & 37.9 & 30.8 & & 25.9 & 51.2 & \\
\hline & Once a month & 28.5 & 25.0 & 32.1 & & 25.9 & 31.9 & \\
\hline & Rarely / never & 37.1 & 37.1 & 37.1 & & 48.2 & 16.9 & \\
\hline
\end{tabular}

Sex: G - girls, B - boys; Education: H - higher, S + V - secondary + vocational

Table 3. Amount of consumed liquids and preferred beverages among preschool children depending on sex and the mother's level of education (percentage of subjects)



Sex: G - girls, B - boys; Education: H - higher, S + V - secondary + vocational 


\section{DISCUSSION}

The discussed research in the group of Kraków preschool children showed nutritional deficiencies (particularly concerning the insufficient frequency of consuming some recommended products: vegetables, fruit, whole-grains, milk and dairy products and the relatively frequent consumption of sweets and confectionery products), and the diversity of nutrition depending on the sex of children as well as the level of the mother's education, with an indication of more rational dietary choices among girls and children of mothers with higher education. The described nutritional deficiencies may limit the nutritional and health value of food rations, and in particular, cause an imbalanced supply of certain nutrients, reducing the potential developmental possibilities of children.

Rational nutrition is a key determinant in the proper development of children, while negative nutritional choices may increase the risk of developing diet-related diseases at later stages of ontogenesis [14, 18]. It is recommended to regularly eat 4-5 meals a day, which has a positive effect on the rate of energy metabolism, preventing the development of obesity, regulating appetite and delaying the occurrence of fatigue [14]. The results of this study showed that all of the children consumed at least 4-5 meals a day, this number increased due to eating between main meals. The parents' declarations show that they made sure children ate meals regularly. Other studies have also confirmed the dominance of the 5-meal model of nutrition for preschool children [41], however, regularity of eating meals was emphasised to a lesser extent [8]. Also, in new studies among preschool children from Białystok county, at least 4 meals a day were consumed $(84.9 \%$ for girls and $93.8 \%$ in the case of boys) [43]. The results showing that $87 \%$ of the children ate between main meals corresponded with the results of previous research conducted among preschool children from Kraków (86.5\%) [8]. In other Kraków-based studies, it was found that only $26 \%$ snacked in-between meals every day, while $52.8 \%$ of the group snacked sporadically [17]. Preschool children from Pabianice most frequently chose sweets and fruit [4], while children from Biała Podlaska snacked on fruit and vegetables (44\% girls and 39\% boys) [43].

An important role in shaping the model of a child's nutrition is played by parents who are their role models. Common meals $[6,14,48]$ are a good form of consolidating proper eating habits. In the author's research, it was shown that $92 \%$ of children consumed meals together with their parents (most often supper). Supper, as the meal most often consumed by children together with their parents, has also been noted in other studies [20].
The recommended diversity in the diet is ensured by the inclusion of products from various food groups. According to the Pyramid of Healthy Nutrition and Lifestyle for Children and Youth, the basis of a daily diet for children and teenagers should be vegetables and fruit as a source of dietary fibre as well as vitamins and minerals [13]. The author's research showed that less than half of the children consumed vegetables every day. The insufficient intake of vegetables among children was also confirmed by other authors $[4,6,8,17,20,31,37,41,43]$. The results of the aforementioned research, indicating almost twice as many children consuming fruit every day rather than vegetables, corresponded with the tendencies described by Harton et al. [11], whereas in earlier Kraków studies, the daily consumption of vegetables and fruit concerned a similar percentage of children (about 30\%) [8]. The limited implementation of the recommendations for the consumption of vegetables and fruit is also described in the case of American preschoolers [23]. A low intake of vegetables and fruits may generate a risk of deficits in the supply of potassium and fibre in the food rations of preschool children, as confirmed by research conducted among preschools in Lublin [22]. Diets lacking in fruit and vegetables are poor in bioactive components, including vitamins, minerals, polyphenols, carotenoids, dietary fibre, which may increase the risk of various illnesses in the future, including cardiovascular- and cancerrelated diseases.

An important group of products includes cereals as basic energy sources, indicating the importance of whole-grains with higher nutritional value. The recommended daily consumption of whole-grain cereal products in this study concerned a small percentage of children. In other studies, a similar amount of consuming whole-grain cereal products was demonstrated [4, 8, 37, 44]. In another group of children, wholemeal bread was regularly consumed by about $30 \%$ of the subjects [33]. The low frequency of consuming whole-grain cereal products has also been described among preschoolers from Białowieża county [43]. A low intake of wholemeal cereal products may generate a risk of fibre supply deficiencies in food rations, as confirmed by studies conducted in Lublin [22], and also Mexican kindergartens [15].

During the period of a child's intensive growth and development, there is a high demand for wholesome proteins originating from meat, poultry, fish, eggs and dairy products. Some studies have confirmed the normative [35], and others the supra-normative supply of protein $[22,39]$ in the diet of preschool children. This study proved that among protein products, children most often chose: milk and dairy products, meat and poultry, eggs and fish. 
A particularly important group of food products for preschool children constitutes milk and dairy products, because they provide wholesome protein and calcium necessary for proper bone growth. Calcium intake, due to meeting growing needs, should be high [5] - especially to achieve the so-called peak bone mass, while some studies have shown calcium deficiencies in children's food rations [5, 39]. Children should consume 3-4 glasses of milk per day, and part of the recommended consumption can be replaced by fermented milk beverages and dairy products $[13,14,40]$. This research indicated a low level of consuming dairy products. Other studies also confirmed the observed trends in the preferred frequency of consuming dairy products by children [ 4 , $8,17,37]$. Insufficient consumption of dairy products, including fermented ones, was also demonstrated among preschoolers from Białowieża county [43] and children from 231 Polish kindergartens [31]. The low intake of milk and its products may generate the risk of calcium supply deficits, which has been confirmed by studies among preschool children [23, 32, 35].

Another group of food products included in the pyramid of nutrition for children and teenagers includes meat, eggs, fish and legume seeds that provide proteins necessary for the normal growth of children. Preschoolers should consume 2 portions of these products daily, with lean meats and cold-cuts, as well as oily sea fish. Fish, as a valuable source of mineral salts and omega 3 fatty acids, should be consumed twice a week $[13,14]$. In the discussed research, it was shown that preschool children mostly ate fish several times a week. In earlier studies, a group of Kraków preschool children recorded lower intake of fish (16.7\% several times a week and $50 \%$ once a week) [8]. The low consumption of fish by children was also noted in other groups of preschoolers from the Kraków [20] and Bialski [43] populations. Low intake of fish can lower the supply of omega 3 PUFA acids and heme iron and vitamin $\mathrm{D}$, also described in other studies among children [5, 24, 38, 39, 46].

Children and adolescents constitute a population group excessively consuming sweets and confectionery as well as fast food products, low nutritional density and high energy products [3], with high content of simple sugars, salts, fats and trans fatty acids, which may increase the risk overweightness and obesity, which was also confirmed among Kraków kindergarten children [17]. The author's research showed the rather occasional consumption of fast food products and frequent consumption of sweets/confectionery. In earlier Kraków studies, preschool children also reported lower consumption of fast food than sweets [8]. Excessive consumption of sweets and sweetened beverages has been described among preschoolers from Białowieża county [43] and Pabianice [4].
An important aspect of children's nutrition is also proper fluid replenishment [14]. It is recommended that pres-choolers drink about 1,000-1,400 ml/ day, with an indication of much water and other unsweetened beverages [14, 42]. The diet should eliminate sweetened fizzy beverages, which due to the high content of simple sugars, may increase the risk of excessive body mass and tooth decay $[10,30$, $34,42]$. In the author's research, it was demonstrated that the children usually drank 1.0-1.5 litres of fluids a day, most often choosing mineral water and tea, less frequently fruit juices, and the least, sweetened fizzy beverages. Previous studies have shown that preschool children from the Kraków community consumed fruit juice $(62.7 \%)$ and tea $(45.2 \%)$ most often [8]. Other studies confirmed that preschool children preferred: fruit juices, mineral water and sweetened fizzy beverages [45], as well as fruit juices and mineral water [7]. Therefore, the research indicates a variety of taste preferences among children and perhaps an increase in the health awareness of parents.

The discussed research shows diversification in some dietary choices of preschool children depending on gender, with an indication of more frequent consumption of recommended vegetables and fruit, wholemeal bread, dairy products among girls, and sweets/confectionery among boys who also consumed more meals during the day. Therefore, it was found that the consumption of products with high nutritional density, conditioning the proper course of development processes among girls, was more widespread. The established regularities corresponded with the results of studies by other authors, confirming the diversity of some dietary choices depending on gender. In the Kraków group of teenagers, the consumption of sweetened fizzy beverages was more frequently noted among boys than girls [9]. Also, in the study by Merkiel and Chalcarz [28], a differentiated supply of some macronutrients in preschool children's food rations depending on gender was noted, including a higher sucrose consumption by boys than girls $(21.2 \%$ vs. $19.7 \%$ energy).

The discussed research has also shown the association of some dietary choices of preschool children with the level of their mothers' education. There was a tendency for more rational dietary behaviours associated with more regular consumption of more meals and more frequent consumption of recommended products (vegetables and fruit, wholegrain cereals, milk and dairy products, fish and eggs), and less frequent consumption of non-recommended products (sweets/confectionery products and fast food, and a smaller preference for sweetened fizzy beverages) by the children of mothers with higher education. The described, more favourable dietary choices of children whose mothers had higher education favoured 
a greater supply of certain nutrients, including vitamins and mineral salts (antioxidants, potassium, magnesium and iron), components essential for the development and health of children. The tendency to undertake more rational dietary behaviours among preschool children, along with the increase in the level of education of mothers, one of the indicators of socio-economic status of families, also corresponded with the results of other authors in the Polish and world literature. In the research by Łoś-Rycharska and Niectawska [25], it was found that children of mothers with higher education were less likely to consume fast-food products, and more often chose vegetables and fruit than those of mothers with lower education (primary, vocational and secondary). European surveys covering 7 countries also showed that a higher level of the mother's education was conducive to more prohealth behaviours among children [12]. Relationships between socio-economic status and health behaviours of children and adolescents are also described in other studies [1, 19, 48]. Earlier Kraków studies on the socio-demographic determinants of nutritional behaviour among preschool children revealed relationships between the children's eating behaviours and the level of parents' education and family income [19]. A Brazilian study also confirmed the predictive importance of socio-economic factors on the development of indicators regarding nutritional status among children aged 0-3, with an indication of more favourable rates for children of mothers with higher socio-economic status [2]. Diversity in the nutritional value of the diet depending on living environment has been described among Mexican preschool children, with an indication of more favourable results among urban children than in rural areas [15]. Other Polish studies on diet structure and body mass index among preschool children in relation to place of residence showed differences in anthropometric indicators and diet structure depending on region (children from the western region of Poland had a significantly higher BMI than those from other regions) [36].

There is a need for further research and to monitor children's nutritional behaviour, promoting the nutritional education of children and their parents as well as the preschool staff, assuming that eating habits are shaped from the earliest possible age, bearing in mind that a varied and balanced diet is an important element in raising health potential and prevention of chronic diseases [19, 26, 27, 28, 29, 31, 43, 47].

\section{CONCLUSIONS}

1. Irregularities in the nutrition of preschool children from the Krakow environment have been found, particularly concerning the insufficient frequency of consuming recommended products, including: vegetables, fruits, whole-grain cereal products, dairy products and fish.

2. Diversification of some nutrition choices among preschool children from the Kraków environment, depending on the sex of children and the mother's level of education, was indicated, suggesting more favourable dietary behaviours of girls than boys and regarding children of mothers with higher education rather than secondary and vocational education.

3. The described tendencies confirmed that there is a need to research and monitor the nutritional habits of preschool children and their conditions, as well as the nutritional education of children and their parents, taking the level of mothers' education into account.

\section{Conflict of interest}

The author declare no conflict of interest.

\section{REFERENCES}

1. Aktop A.: Socioeconomic status, physical fitness, self-concept, attitude toward physical education, and academic achievement of children. Perceptual \& Motor Skills 2010; 110(2): 531-546. doi.org/10.2466/ pms.110.2.531-546.

2. Boo F.L., Mateus M.C., Duryea S.: Analysis of socioeconomic gradients in the development of children aged 0-3 years in Fortaleza, Northeastern Brazil. Rev Saude Publica 2018; 52: 84. doi: 10.11606/ S1518-8787.2018052000525.

3. Bowman S., Gortmaker S., Ebbeling C., Pereira M., Ludwig $D$.: Effects of fast-food consumption on energy intake and diet quality among children in a National Household Survey. Pediatrics 2004; 113(1): 112-118.

4. Chalcarz W., Merkiel S., Hodyr Z.: Food behaviour in preschool children from Pabianice. New Medicine 2009; 13(1): 7-12.

5. Charzewska J., Weker H.: Ogólnopolskie badania nad zawartością wapnia i witaminy $\mathrm{D}$ w dietach dzieci w wieku 4 lat. [Nationwide research on the content of calcium and vitamin $\mathrm{D}$ in the diets 4-year-old children]. Pediatr Współcz 2006; 8(2): 107-109 (in Polish).

6. Cooke J.L., Wardle J., Gibson E.L., Sapochnik M., Sheiham A., Lawson M.: Demographic, familial and trait predictors of fruit and vegetable consumption by pre-school children. Public Health Nutr 2004; 7(2): 295-302.

7. Czerwonogrodzka-Senczyna A., Kryńska P., Majcher A., Rumińska M., Jeznach-Steinhagen A., Pyrżak B.: Wpływ czynników środowiskowych na występowanie otyłości u dzieci do 7 roku życia [The influence of environmental factors on obesity in children up to 7 years old]. Endokrynol Pediatr 2014; 13(47): 14-24 (in Polish).

8. Gacek M.: Sposób żywienia dzieci przedszkolnych ze środowiska wielkomiejskiego [Dietary patterns in nursery school children from an urban environment]. Rocz Panstw Zakl Hig 2012; 63(4): 477-482 (in Polish). 
9. Gacek M.: Dietary Habits and Locus of Control Assessed in Middle-school Pupils from the Malopolska Region of Poland. Rocz Panstw Zakl Hig 2013; 64(2): 129-134.

10. Gidding S.S., Dennison A.B., Birch L.L.: Dietary recommendations for children and adolescents. A guide for practitioners. Consensus statement from the American Heart Association. Circulation 2005; 112: 2061-2075.

11. HartonA., FlorczakJ., Myszkowska-RyciakJ., Gajewska $D .:$ Spożycie warzyw i owoców przez dzieci w wieku przedszkolnym . [Fruit and vegetable consumption by preschool children]. Probl Hig Epidemiol 2015; 94(4): 732-736 (in Polish).

12. Inskip H., Baird J., Barker M., Briley A.L., D'Angelo S., Grote V., Koletzko B., Lawrence W., Manios Y., Moschonis G., Chrousos G.P., Poston L., Godfrey $K$.: Influences on adherence to diet and physical activity recommendations in women and children: Insights from six European studies. Ann Nutr Metab 2014; 64(3-4): 332-339. doi: 10.1159/000365042.

13. Jarosz M.: Piramida Zdrowego Żywienia i Stylu Życia Dzieci i Młodzieży (4-18 lat) IŻŻ w Warszawie [Pyramid of healthy nutrition and lifestyle for children and youth (age 4-18)]. (https://ncez.pl) (access date: 12.02.2019) (in Polish).

14. Jarosz M.: Zasady prawidłowego żywienia dzieci i młodzieży oraz wskazówki dotyczące zdrowego stylu życia [The rules of healthy eating for children and adolescents along with tips for a healthy lifestyle]. Warszawa, IŻŻ 2008 (in Polish).

15. Jiménez-Aguilar A., González Castell D., FloresAldana M., Mundo-Rosas V., Hernández-Cordero S., García-Feregrino R.: Dietary intake and adequacy in Mexican preschool children: National Health and Nutrition Survey 2012. Nutr Hosp. 2018, 35(5): 11861194. doi: 10.20960/nh.1843.

16. Kędzior A., Jakubek-Kipa K., Brzuszek M., Mazur A.: Trendy w występowaniu nadwagi i otyłości u dzieci na świecie, w Europie i w Polsce. [Trends in prevalence of childhood overweight and obesity on the world, in Europe and in Poland]. Endokrynol Ped 2017; 58: 4148 (in Polish). doi:10.18544/EP-01.16.01.1662.

17. Kolarzyk E., Janik A., Kwiatkowski J.: Zwyczaje żywieniowe dzieci w wieku przedszkolnym [Nutritional habits of pre-school children]. Probl Hig Epidemiol 2008; 89(4): 527-532 (in Polish).

18. Kostecka M.: Prawidłowe żywienie dzieci w wieku przedszkolnym jako niezbędny element profilaktyki chorób cywilizacyjnych. [Proper nutrition preschool children as an essential element of prevention of lifestyle diseases]. Piel Zdr Publ 2013; 3(3): 257-263 (in Polish).

19. Kozioł-Kozakowska A., Piórecka B., SchlegelZawadzka M.: Wpływ postaw rodzicielskich na sposób żywienia dzieci w wieku przedszkolnym w Krakowie na tle uwarunkowań socjo-demograficznych. [The influence of parental attitudes on diet of preschool children in Cracow against the background of sociodemographic determinants]. Zdr Publ \& Zarządzanie
2014; 12(1): 82-89 (in Polish). doi:10.4467/20842627 OZ.14.009.2901.

20. Koziot-KozakowskaA., Piórecka B., ŻwirskaJ., Jagielski P., Schlegel-Zawadzka M.: Ocena sposobu żywienia dzieci w wieku przedszkolnym $\mathrm{z}$ regionu Krakowa z uwzględnieniem charakterystyki socjoekonomicznej. [Assessment of heating habits of pre-school children attending kindergartens in the region of Krakow with referral to socio-economic characteristics]. Probl Hig Epidemiol 2007; 88(4): 422-427 (in Polish).

21. Kułaga Z., Różdżyńska-Świątkowska A., Grajda A., Gurzkowska B., Wojtyło M., Góźdź M., Świąder-Leśniak A., Litwin M.: Siatki centylowe dla oceny wzrastania i stanu odżywienia polskich dzieci i młodzieży od urodzenia do 18 roku życia. [Percentile charts for growth and nutritional status assessment in Polish children and adolescents from birth to 18 year of age]. Standardy Medyczne/Pediatria 2015; 12: 119-135 (in Polish).

22. Kwiecień M., Winiarska-Mieczan A., Danek-Majewska A., Kiczorowska B., Olcha M.: Ocena wartości odżywczej przedszkolnych racji pokarmowych ze szczególnym uwzględnieniem składników mineralnych. [Assessment of nutritional value of food rations for preschool children with particular emphasis on mineral content]. Probl Hig Epidemiol 2015; 96(4): $742-745$ (in Polish).

23. Ling J., Zahry N.R., Wasilevich E., Robbins L.B.: Dietary Intake Among Head Start Preschooler-caregiver Dyads. J Pediatr Nurs 2018; 42: 65-72. doi: 10.1016/j. pedn.2018.07.003.

24. Lopez-Molina M., Santillan C., Murillo M., Valls A., Bosch L., Bel J., Granada M.L.: Measured Free 25-hydroxyvitamin D in Healthy Children and Relationship to Total 25-hydroxyvitamin D, calculated free 25-hydroxyvitamin D and vitamin D binding protein. Clin Biochem 2018; 61: 23-27. doi: 10.1016/j. clinbiochem.2018.08.007.

25. Łoś-Rycharska E., Niecławska A.: Analiza wybranych cech diety dzieci w wieku przedszkolnym i poniemowlęcym w zależności od sytuacji społecznoekonomicznej rodzin. [Analysis of selected features of the diet of pre-school and paternity children depending on the socio-economic status of families]. Pediatr Pol 2010; 85(5): 471-480 (in Polish). doi: 10.1016/S00313939(10)70539-4.

26. Merkiel S., Chalcarz $W$.: Selected indices of health status in preschool children from Pila and their families as a risk factor of diet-related diseases. Rocz Panstw Zakl Hig 2015; 66(2): 159-165.

27. Merkiel S., Chalcarz $W$. : Review of the studies on nutrition in Polish preschool children. Part 1. Preschool menus. Rocz Panstw Zakl Hig 2016; 67(3): 223-235.

28. Merkiel S., Chalcarz $W$ : The need for modifying energy intake in preschool children from Pila, Poland. Rocz Panstw Zakl Hig 2016; 67(2): 177-189.

29. Merkiel-Pawłowska S., Chalcarz W.: Review of the studies on nutrition in Polish preschool children. Part 2. Meals prepared at preschool. Rocz Panstw Zakl Hig 2017; 68(1): 15-21. 
30. Michota-Katulska E., Zegan M., Norowska Z.: Wybrane zachowania żywieniowe i higieniczne u dzieci w wieku przedszkolnym $\mathrm{w}$ aspekcie ryzyka wystąpienia próchnicy. [Diet and oral hygiene in preschool-aged children in the context of dental caries risk]. Żyw Człow Metab 2015; 42(4): 218-228 (in Polish).

31. Myszkowska-Ryciak J., Harton A.: Impact of nutrition education on the compliance with model food ration in 231 preschools, Poland: Results of eating healthy, growing healthy program. Nutrients 2018; 10(10). pii: E1427. doi: 10.3390/nu10101427.

32. Myszkowska-Ryciak J., Harton A.: Implementation of dietary reference intake standards in preschool menus in Poland. Nutrients 2018a; 10(5). pii: E592. doi: 10.3390/nu10050592

33. Newerli-Guz J., Kulwikowska K.: Zachowania żywieniowe i preferencje dzieci w wieku przedszkolnym. [Nutritional habits and preferences of pre-school children]. Zeszyty Naukowe Akademii Morskiej w Gdyni 2014; 86: 80-89 (in Polish).

34. Nielsen S., Popkin B.: Changes in beverage intake between 1977 and 2001. Am J Prev Med 2004; 27(3): 205-210.

35. Orkusz A., Włodarczyk A.: Ocena żywienia dzieci w przedszkolu na podstawie dekadowych jadłospisów. [Assessment of preschool children's decades menus]. Nauk Inż Technol 2014; 1(12): 60-72 (in Polish).

36. Potocka A., Jacukowicz A.: The diet structure and body mass index among Polish preschool children in relation to their place of residence. Dev Period Med 2018; 22(2):153-159.

37. Sadowska J., Krzymuska A.: Ocena uzupełnienia przedszkolnej racji pokarmowej przez rodziców $\mathrm{u}$ dzieci w wieku przedszkolnym. [The estimation of complementation of the nursery school food rations by parents of pre-school children]. Bromat Chem Toksykol 2010; 43(2): 203-211 (in Polish).

38. Sochacka L., Gruszka J.: Wybrane metody profilaktyki niedoboru witaminy $\mathrm{D}$ u dzieci w wieku przedszkolnym podejmowane przez ich rodziców. [Selected methods of preventing vitamin $\mathrm{D}$ deficits in pre-school children applied by their parents]. Med Środow 2015; 18(2): 2631 (in Polish).

39. Sochacka-Tatara E., JacekR., Sowa A., MusiałA.: Ocena sposobu żywienia dzieci w wieku przedszkolnym. [Assessment of preschool children's diet]. Probl Hig Epidemiol 2008; 89(3): 389-394 (in Polish).

40. StankiewiczJ., Lange M.: Mleczne napoje fermentowane w żywieniu dzieci w wieku przedszkolnym. [Fermented milk drinks in the diet of nursery age children]. Bromat Chem Toksykol 2012; 45(2): 191-195 (in Polish).
41. Stankiewicz M., Pęgiel-Kamrat J., Zarzeczna-Baran M., Jankowski M., Pieszko-Klejnowska M., LysiakSzydlowska W: Styl żywienia dzieci przedszkolnych w opinii ich rodziców. [Nutritional habits of preschool children in parents' opinion]. Probl Hig Epidemiol 2006; 87(4): 273-277 (in Polish).

42. Stanowisko Zespołu Ekspertów: Rola prawidłowego nawodnienia $\mathrm{w}$ zdrowym żywieniu oraz pożądane zmiany zwyczajów Polaków dotyczące spożycia płynów. [The role of proper hydration in healthy nutrition and the desired changes in Poles' habits concerning the consumption of fluids]. Żyw Człow Metab 2017; 44(4): 182-185.

43. Stempel P., Galczak-Kondraciuk A., Czeczelewski J., Koldej M.: Assessment of nutritional behaviour of children aged 3-7 from selected kindergartens in Biala Podlaska county. Rocz Panstw Zakl Hig 2018; 69(3): 289-297.

44. Sweitzer S.J., Briley M.E., Roberts-Gray C., Hoelscher D.M., Harrist R.B., Staskel D.M., Almansour F.D.: Lunch is in the bag: Increasing fruits, vegetables, and whole grains in sack lunches of preschool-aged children. J Am Diet Assoc 2010; 110(7): 1058-1064. doi: 10.1016/j.jada.2010.04.010.

45. Tkaczuk M., Wiercioch-Klin B., Szymańska J.: Dobowa analiza żywienia dzieci z uwzględnieniem kariogenności stosowanych produktów spożywczych. [Twenty-four-hour analysis of nutrition of children and cariogenicity of food products consumer]. Med Og Nauk Zdr 2012; 18(4): 448-452 (in Polish).

46. Trafalska E.: Assessing diets for energy and nutrients content in nursery school children from Lodz, Poland. Rocz Panstw Zakl Hig 2014; 65(1): 27-33.

47. Ward S., Blanger M., Donovan D., Vatanparast H., Muhajarine N., Engler-Stringer R., Leis A., Humbert M.L., Carrier N.: Association between childcare educators' practices and preschoolers' physical activity and dietary intake: A cross-sectional analysis. BMJ Open 2017; 7(5): e013657. doi: 10.1136/bmjopen-2016-013657.

48. Wolnicka K., Taraszewska A.M., Jaczewska-Schuetz $J$., Jarosz M.: Factors within the family environment such as parents' dietary habits and fruit and vegetable availability have the greatest influence on fruit and vegetable consumption by Polish children. Public Health Nutr 2015; 18(15): 2705-2711. doi: 10.1017/ S1368980015000695.

Received: 21.12 .2018

Accepted: 04.03.2019

This article is available in Open Access model and licensed under a Creative Commons Attribution-Non Commercial 3.0.Poland License (CC-BY-NC) available at: http://creativecommons.org/licenses/by-nc/3.0/pl/deed.en 